\title{
DOT1L wt Allele
}

National Cancer Institute

\section{Source}

National Cancer Institute. DOT 1L wt Allele. NCI Thesaurus. Code C73678.

Human DOT $1 \mathrm{~L}$ is located in the vicinity of $19 \mathrm{p} 13.3$ and is approximately $66 \mathrm{~kb}$ in length.

This allele, which encodes histone lysine $\mathrm{N}$-methyltransferase, $\mathrm{H} 3$ lysine- 79 specific protein, may play a role in transcriptional regulation and epigenetic modification of chromatin. 